\title{
Photoperiod Influences the Effects of Ghrelin and Serotonin Receptor Agonist on Growth Hormone and Prolactin Secretion in Sheep
}

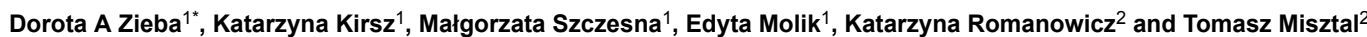 \\ ${ }^{1}$ Department of Animal Biotechnology, University of Agriculture in Krakow, Poland \\ ${ }^{2}$ Department of Endocrinology, The Kielanowski Institute of Animal Physiology and Nutrition, Polish Academy of Sciences, Poland.
}

"Corresponding author: Dorota A. Zieba, Agricultural University of Krakow, Department of Animal Biotechnology, 1B Redzina Street, $30-248$ Krakow, Poland, Tel: +48 1242972 24; Fax: + 481242975 47; Email: rzzieba@cyf-kr.edu.pl

Received date: May 25, 2015; Accepted date: July 14, 2015; Published date: July 18, 2015

Copyright: $@ 2015$ Zieba DA et al. This is an open-access article distributed under the terms of the Creative Commons Attribution License, which permits unrestricted use, distribution, and reproduction in any medium, provided the original author and source are credited.

\begin{abstract}
Objective: Recent studies have identified a novel heterodimer involving the ghrelin receptor (GHS-R1A) and the 5-HT2C receptor, a subtype of serotonin receptors. Whether or not interactions between GHS-R1A and the 5-HT2C receptor exist and how they are modulated by photoperiod and nutritional status in seasonally animals remains unknown. The aims of this study were to determine the effects of ghrelin and a 5-HT2B/2C serotonin receptor agonist, 1-(3-chlorophenyl) piperazine hydrochloride (m-CPP), on GH and PRL secretion under the influence of nutritional status and photoperiod.
\end{abstract}

Methods: Normally fed $(n=12)$ or fasted $(n=12)$ ewes were assigned to one of 4 groups and treatments: 1$)$ control (saline); 2) ghrelin $(2.5 \mu \mathrm{g} / \mathrm{kg}) ; 3) \mathrm{m}$-CPP $(2.5 \mathrm{mg} / \mathrm{kg}) ; 4)$ ghrelin followed by $\mathrm{m}$-CPP were infused once at the beginning of the study for groups 1, 2 and 3; in group 4, ghrelin was administered at $15 \mathrm{~min}$, and $\mathrm{m}$-CPP at $30 \mathrm{~min}$. Blood samples were collected at 15 -min intervals for $3 \mathrm{~h}$ during the short day (SD) and long day (LD) season.

Results: Ghrelin and m-CPP enhanced $(p<0.05) \mathrm{GH}$ secretion in fasted ewes during LD. The m-CPP significantly decreased $\mathrm{GH}$ concentrations in fasted ewes during SD. Prolactin concentrations were lower $(p<0.01)$ in normally fed ewes after the ghrelin ${ }^{+} \mathrm{m}-\mathrm{CPP}$ treatment compared to treatment with $\mathrm{m}$-CPP alone.

Conclusion: There were interactions among ghrelin, serotonin, photoperiod and metabolic status that influenced $\mathrm{GH}$ and PRL secretion in ewes. Using an ovine model, our work provides a basis for future studies of the pathogenesis of metabolic disorders associated with alterations in nutritional status and day length.

Keywords: Seasonality; Growth Hormone; Ghrelin; Sheep; Prolactin; Serotonin

\section{Introduction}

Sheep are seasonal breeders and also display seasonality of metabolic function, a useful aspect of their utility as a model for maintenance of energy homeostasis in different periods of food availability. Ghrelin was identified as the endogenous ligand for the growth hormone secretagogue receptor (GHS-R1a) by a reverse pharmacological approach [1], it potently stimulates growth hormone (GH) secretion with little effect on prolactin (PRL) concentration [2]. Thus, GHS-R1a was designated the ghrelin receptor [3]. GHS-R1a is a class I G protein-coupled receptor (GPCR) [4]. GHS-R1a interacts with other GPCRs and exists and functions as dimers or even higher structural oligomeric complexes [5]. The serotonin 2C (5-HT2C) receptor is another centrally expressed GPCR involved in satiety signaling [6]. Interestingly, interactions between the serotonin (5hydroxytryptamine, 5-HT) and ghrelin signaling pathways have been described in rodents [7]. No study in ruminants has examined ghrelin and serotonin cross-talk in the regulation of sommatotropic and lactotropic hormones, particularly the effect of day length on factors engaged in energy homeostasis as GH and PRL in photoperioddependent species.
The photoperiodic regulation of PRL secretion by serotonin persists throughout the year in seasonally breeding mammals. Circulating concentrations of PRL peak in the summer and then decline during the winter months [8]. The low circulating concentrations of serotonin and its metabolites observed in the winter can be artificially restored using light pulses [9]. To examine the postulated involvement of ghrelin and serotonin in the control of GH and PRL secretion, this study aimed to assess the influence of the season/day length on the ghrelin- and serotonin-mediated release of these somatomammotropic hormones in ewes. The specific aim of the present experiment was to assess whether the synergistic or antagonistic effect of $\mathrm{m}$-CPP, a mixed agonist that binds principally to $5-\mathrm{HT} 2 \mathrm{~B} / 2 \mathrm{C}$ receptors, with ghrelin influences $\mathrm{GH}$ and PRL concentrations in seasonal breeding sheep.

\section{Materials and Methods}

All procedures performed on live animals in this study were approved by the First Local Ethical Committee on Animal Testing in Kraków, Poland (protocol \#80/2012). The experiments described in this paper were performed at the Department of Animal Biotechnology, Agricultural University of Kraków, Poland. 
Citation: Zieba DA, Kirsz K, Szczesna M, Molik E, Romanowicz K, et al. (2015) Photoperiod Influences the Effects of Ghrelin and Serotonin Receptor Agonist on Growth Hormone and Prolactin Secretion in Sheep. J Neurol Neurophysiol 6: 301. doi: $10.4172 / 2155-9562.1000301$

Page 2 of 7

\section{Chemicals}

Ovine ghrelin was purchased from PolyPeptide Laboratories (Strasbourg, France) and dissolved in saline. The mixed 5-HT2B/2C serotonin receptor agonist 1-(3-chlorophenyl) piperazine hydrochloride (mCPP) was purchased from Tocris Biosciences (Bristol, UK) and dissolved in saline.

\section{Animal Model}

The present study utilized 24 Polish Longwool ewes, which exhibit pronounced reproductive seasonality. The breeding season commences during shortened days (SD; August-December), and a period of seasonal anestrus (non-breeding season) occurs as days become longer (LD; February-June). The animals were 3 years old and weighed $60 \pm 3$ $\mathrm{kg}$, and they were housed in individual pens under natural photoperiodic and thermoperiodic conditions. All sheep had a good body condition score $(\mathrm{BCS}=3)$. The present experiments were performed during the LD photoperiods from April to May, during which the average day length in Poland is approximately $15 \mathrm{~h}$, and during the SD season (October and November), during which the day length averages approximately $10 \mathrm{~h}$. The ewes had been ovariectomized and implanted with estradiol-releasing subcutaneous implants as described in our earlier studies investigating the effects of anorectic and orexigenic peptides in sheep [10]. This ovine experimental model is a widely accepted neuroendocrine model developed to avoid the confounding effects of the ovarian cycle on hormonal interactions and to provide constant physiological concentrations of estrogens as a source of steroid-mediated feedback on the secretory activity of the hypothalamus and adenohypophysis [10]. These implants are designed to produce basal circulating concentrations of estradiol-17 $\beta$ of 2-4 $\mathrm{pg} / \mathrm{ml}$ as reported previously [11].

\section{Experimental Procedures and Treatments}

During both seasons, the same ewes $(n=24)$ were randomly assigned to two groups of equivalent size ( $n=12 /$ group). In the first group, the ewes were fasted for $48 \mathrm{~h}$ before the beginning of the experiment, whereas animals in the second group received a diet formulated to provide $100 \%$ of the National Research Institute of Animal Production's recommendation for maintenance [12] twice daily $(0700$ $\mathrm{h}$ and $1400 \mathrm{~h}$ ). Water and mineralized salt licks were available ad libitum to animals in both groups. In the morning of the day of intensive blood collection, four randomly selected sheep from each group were individually restrained in sheep carts and fitted with indwelling jugular catheters. Blood samples $(5 \mathrm{ml})$ were collected at 15-min intervals for $3 \mathrm{~h}$ beginning immediately before the first infusion. The blood samples were collected into tubes containing 150 $\mu \mathrm{l}$ of a solution containing heparin $(10,000 \mathrm{IU} / \mathrm{ml})$ and $5 \%(\mathrm{wt} / \mathrm{vol})$ EDTA, and the samples were immediately placed on ice. The plasma was separated by centrifugation and then stored at $-20^{\circ} \mathrm{C}$ for hormone analyses at a later date. The treatments for each subset of ewes were replicated three times at approximately weekly intervals.

The ewes were randomly allocated to the following treatment groups: Group 1, control (saline); Group 2, ghrelin (GHRL; $2.5 \mu \mathrm{g} / \mathrm{kg}$ body weight [b.w.]); Group 3, m-CPP (2.5 mg/kg b.w.); and Group 4, GHRL and $\mathrm{m}$-CPP at the same doses in in Groups 2 and 3. Saline, ghrelin and $\mathrm{m}$-CPP were infused intravenously (i.v.) $15 \mathrm{~min}$ after the first blood sample was collected at time 0 during the 3 -h experiment. In Group 4, the ewes received $\mathrm{m}$-CPP $15 \mathrm{~min}$ after the ghrelin treatment (time 0 ), and the remaining animals received a volume- matched dose of saline (Figure 1). The doses of ghrelin and $\mathrm{m}$-CPP used in this study were based on our previous experiments [10] or other earlier studies [13].

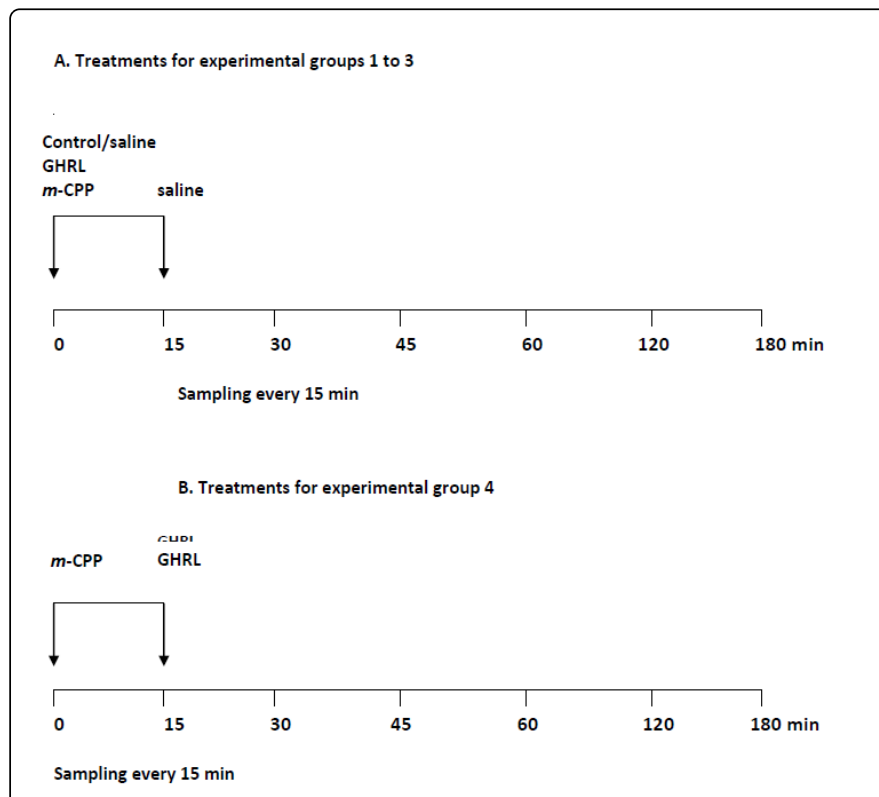

Figure 1: Experimental design and treatments. Sheep were subjected to short days (SD; $9 \mathrm{~h}$ light:15 $\mathrm{h}$ darkness) for two months (October-November) followed by two months (April-May) of long days (LD; $15 \mathrm{~h}$ light:9 $\mathrm{h}$ darkness). In both seasons, one group $(n=12)$ received food freely, and the other group $(n=12)$ was fasted for $48 \mathrm{~h}$ before the initiation of the experiment. The following treatments were used: 1) saline (control), 2) ghrelin ( $2.5 \mu \mathrm{g} / \mathrm{kg} \mathrm{b.w.)}$, 3) $\mathrm{m}-\mathrm{CPP}$ (serotonin $5-\mathrm{HT} 2 \mathrm{~B} / 2 \mathrm{C}$ receptor agonist; $2.5 \mathrm{mg} / \mathrm{kg}$ b.w.) or 4) ghrelin with $\mathrm{m}$-CPP. Arrows indicate intravenous (i.v.) injections administered at 0 or $15 \mathrm{~min}$ of the 180 -min experimental period. Blood samples $(5 \mathrm{ml})$ were collected at 15 -min intervals throughout the experiment.

\section{Hormone Assays}

\section{Plasma Concentrations of Estradiol}

Circulating concentrations of estradiol were determined by EIA using a commercially available kit (DRG Instruments $\mathrm{GmbH}$; Marburg, Germany) according to the manufacturer's specifications. All samples were analyzed in duplicate in a single assay. The intra- and interassay coefficients of variation (CVs) were $<6.4 \%$. The sensitivity of the assay was $1.7 \mathrm{pg} / \mathrm{ml}$.

\section{Plasma Concentrations of Growth Hormone}

Growth hormone concentrations were determined by a validated radioimmunoassay (RIA) using anti-bovine GH, anti-rabbit $\gamma$-globulin antisera and a bovine GH standard (NIDDK-GH-B-1003A) as previously described by Dvorak et al. [14] The assay sensitivity was 0.6 $\mathrm{ng} / \mathrm{ml}$, and the intra- and interassay CVs were $6.1 \%$ and $9.8 \%$, respectively. 
Citation: Zieba DA, Kirsz K, Szczesna M, Molik E, Romanowicz K, et al. (2015) Photoperiod Influences the Effects of Ghrelin and Serotonin Receptor Agonist on Growth Hormone and Prolactin Secretion in Sheep. J Neurol Neurophysiol 6: 301. doi: $10.4172 / 2155-9562.1000301$

Page 3 of 7

\section{Plasma Concentrations of Prolactin}

Prolactin concentrations were assayed by RIA using the doubleantibody method with anti-ovine PRL and anti-rabbit- $\gamma$-globulin antisera according to Wolińska et al. [15]. The assay sensitivity was 2 $\mathrm{ng} / \mathrm{ml}$, and the intra- and interassay CVs were $8.8 \%$ and $11.5 \%$, respectively.

\section{Statistical Analyses}

The hormone data were analyzed using the general linear model (GLM) procedure (PROC GLM) of the Statistical Analysis System (SAS 9.1; SAS Institute Inc., Cary, NC). For hormone comparisons, the overall ANOVA included the diet, treatment, season, replicates within seasons, time within seasons and all 2- and 3-way interactions for repeated measures in a switchback design. Significant treatment $\times$ season interactions resulted in a within-season model that included the diet, treatment, time, and treatment $\times$ time. Following a significant $\mathrm{F}$ test result, the SAS Pdiff procedure was used to compare the means. Following the determination of a significant F-value, the means were compared using Duncan's multiple range test. Differences with $\mathrm{p}<0.05$ were considered statistically significant. Data are expressed as means \pm SEM (the means represent concentrations of each hormones from samples harvested every $15 \mathrm{~min}$ during the 3-h experiment from a particular experimental group analyzed separately for SD and LD photoperiods).

\section{Results}

\section{Plasma Concentrations of Estradiol}

The mean circulating concentration of estradiol in the sheep was $3.96 \pm 0.3 \mathrm{pg} / \mathrm{ml}$.

\section{Plasma Concentrations of Growth Hormone}

Concentrations of $\mathrm{GH}$ after treatment with ghrelin (GHRL; $\mathrm{P}<0.01$ ), $\mathrm{m}-\mathrm{CPP}(\mathrm{P}<0.01)$ and GHRL+m-CPP $(\mathrm{P}<0.01)$ were higher in the LD than the SD season in the 48 -h fasted ewes (Figure $2 \mathrm{~A}$ ). The GHRL and $\mathrm{GHRL}+\mathrm{m}-\mathrm{CPP}$ treatments both augmented $(\mathrm{P}<0.01) \mathrm{GH}$ secretion in fasted ewes during the LD season, and the $\mathrm{m}-\mathrm{CPP}$ and GHRL+m-CPP treatments suppressed $(\mathrm{P}<0.01) \mathrm{GH}$ secretion compared with the control (saline) group during the SD period (Figure 2A). In a subset of normally fed ewes, circulating concentrations of GH were higher $(\mathrm{P}<$ 0.01 ) in the $\mathrm{m}-\mathrm{CPP}$ group during the LD compared with the SD season (Figure 2B). Treatment with GHRL and GHRL $+\mathrm{m}-\mathrm{CPP}$ had no effect $(\mathrm{P}>0.05)$ on $\mathrm{GH}$ secretion in ewes during either season (Figure $2 \mathrm{~B})$. In both seasons, GH release was significantly greater after $\mathrm{m}$-CPP treatment compared with saline-treated controls and those treated with GHRL (Figure 2B). Furthermore, the administration of $\mathrm{m}$-CPP increased GH secretion to a greater extent $(\mathrm{P}<0.01)$ than $\mathrm{GHRL}+\mathrm{m}-$ $\mathrm{CPP}$ in non-fasted animals during the LD season (Figure $2 \mathrm{~B}$ ). In foodrestricted ewes in the LD season, $\mathrm{GH}$ concentrations were higher $(\mathrm{P}>$ 0.05 ) after the GHRL, $m-C P P$ and GHRL+m-CPP treatments as compared to the $\mathrm{GH}$ mean value noted in normally fed sheep the same treated groups (Figure 3).

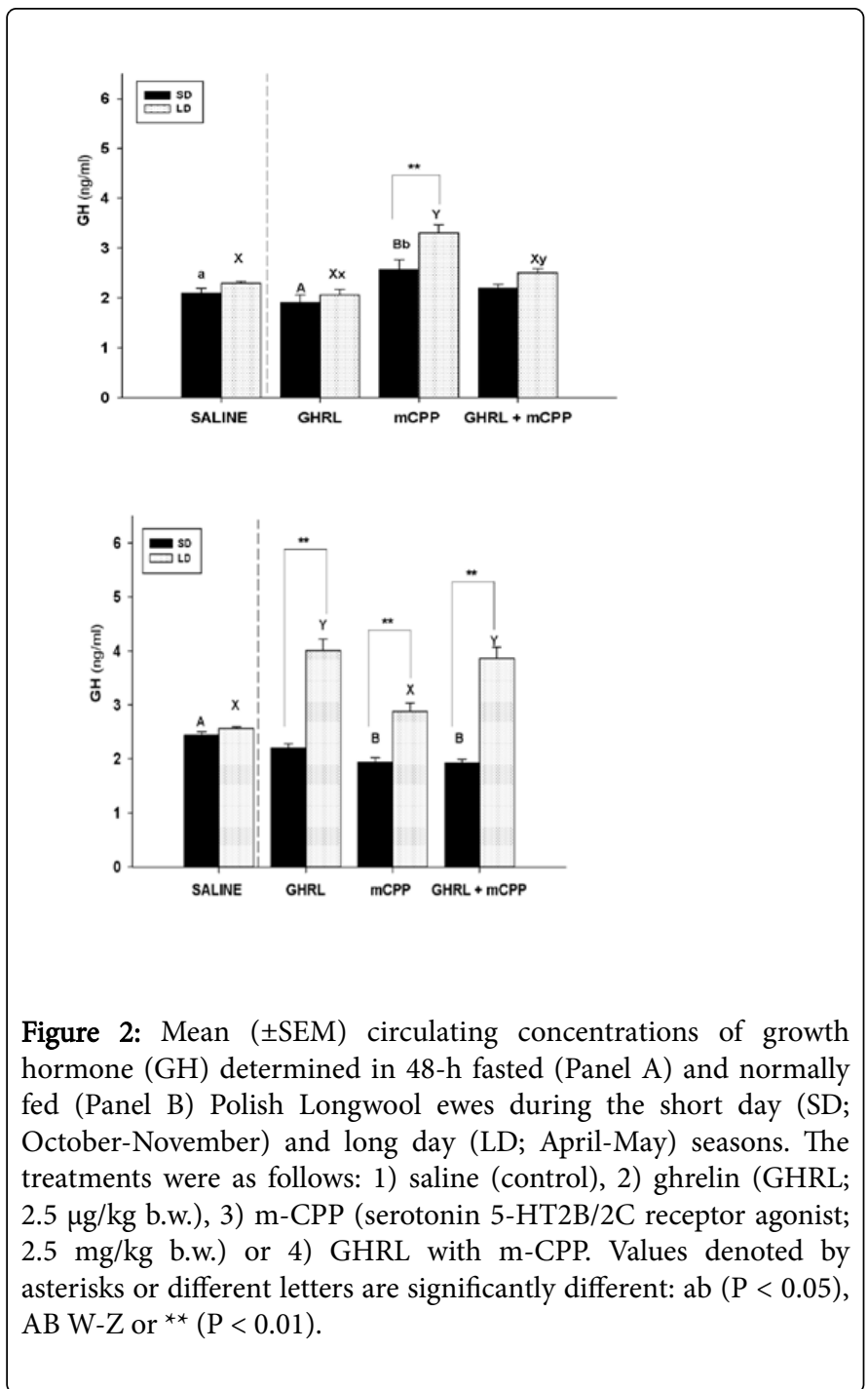

\section{Plasma Concentrations of Prolactin}

In both the fasted and normally fed ewes, peripheral PRL concentrations were significantly higher during the $\mathrm{LD}$ compared to the $\mathrm{SD}$ season (Figures $3 \mathrm{~A}$ and $\mathrm{B})$. GHRL stimulated $(\mathrm{P}<0.05) \mathrm{PRL}$ secretion in fasted ewes during the $\mathrm{SD}$ season (Figure $3 \mathrm{~A}$ ) but decreased $(\mathrm{P}<0.01)$ PRL release in normally fed sheep during $\mathrm{SD}$ photoperiods (Figure 3B). In addition, GHRL treatment enhanced PRL secretion in normally fed ewes in the LD season compared with controls (Figure 3B). Treatments with $\mathrm{m}$-CPP alone and GHRL+mCPP both resulted in significantly greater PRL concentrations than those in GHRL-treated and control groups of ewes regardless of the season or nutritional status (Figures $3 \mathrm{~A}$ and $\mathrm{B}$ ). Finally, treating normally fed ewes with GHRL $+\mathrm{m}-\mathrm{CPP}$ resulted in lower $(\mathrm{P}<0.01)$ circulating PRL concentrations compared with the $\mathrm{m}$-CPP treatment alone (Figure 3B). 
Citation: Zieba DA, Kirsz K, Szczesna M, Molik E, Romanowicz K, et al. (2015) Photoperiod Influences the Effects of Ghrelin and Serotonin Receptor Agonist on Growth Hormone and Prolactin Secretion in Sheep. J Neurol Neurophysiol 6: 301. doi: $10.4172 / 2155-9562.1000301$

Page 4 of 7

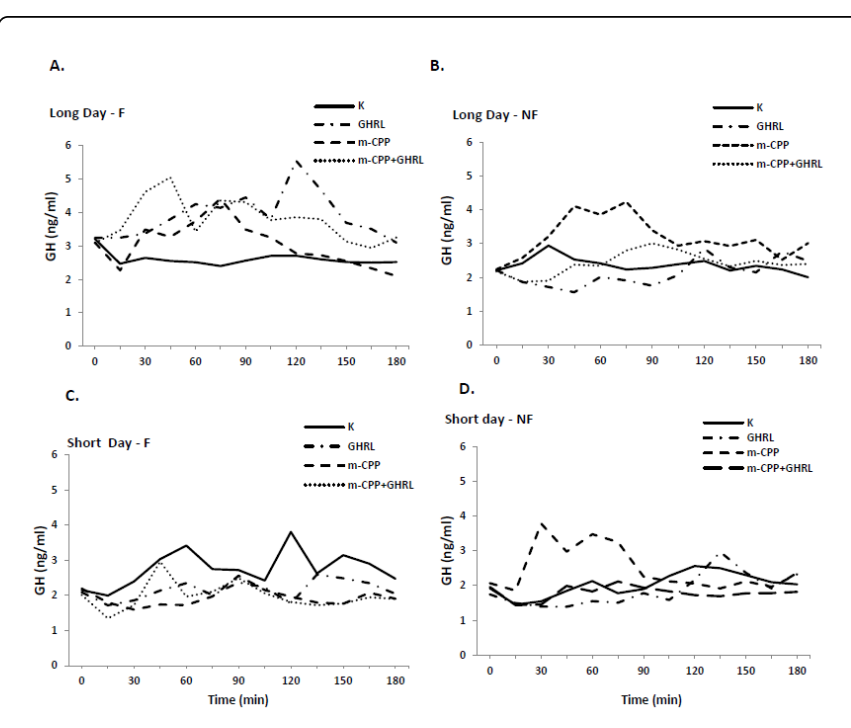

Figure 3: Temporal patterns of circulating growth hormone (GH) in samples collected at 15 -min intervals in 48 -h fasted (F - Panels A and C) and normally fed (NF - Panels B and D) Polish Longwool ewes during the long day and short day seasons. The treatments were as follows: 1) saline (control), 2) ghrelin (GHRL; $2.5 \mu \mathrm{g} / \mathrm{kg}$ b.w.), 3) $\mathrm{m}$-CPP (serotonin $5-\mathrm{HT} 2 \mathrm{~B} / 2 \mathrm{C}$ receptor agonist; $2.5 \mathrm{mg} / \mathrm{kg}$ b.w.) or 4) GHRL with m-CPP.

\section{Discussion}

In ruminants, metabolic function must perfectly respond to factors originating from peripheral organs and tissues that produce modulatory factors. Recent data have demonstrated that hypothalamic central regulation of food intake and energy expenditure is, at least in part, outside the blood-brain barrier [16], and permeability changes with metabolic [17] and photoperiodic state $[18,19]$. In the present experiment, we specifically examined the effects of the $5-\mathrm{HT} 2 \mathrm{~B} / 2 \mathrm{C}$ receptor agonist $\mathrm{m}-\mathrm{CPP}$ and ghrelin administered separately or concurrently on the secretion of GH and PRL in an ovine experimental model using normally fed and nutritionally restricted ewes at two different times of the year (short days vs. long days). This is the first report to demonstrate direct effects of $\mathrm{m}-\mathrm{CPP}$ and ghrelin on $\mathrm{GH}$ and PRL concentrations in sheep and pronounced effects of photoperiod on responses of ovarectomized and estradiol-implanted females to treatments.

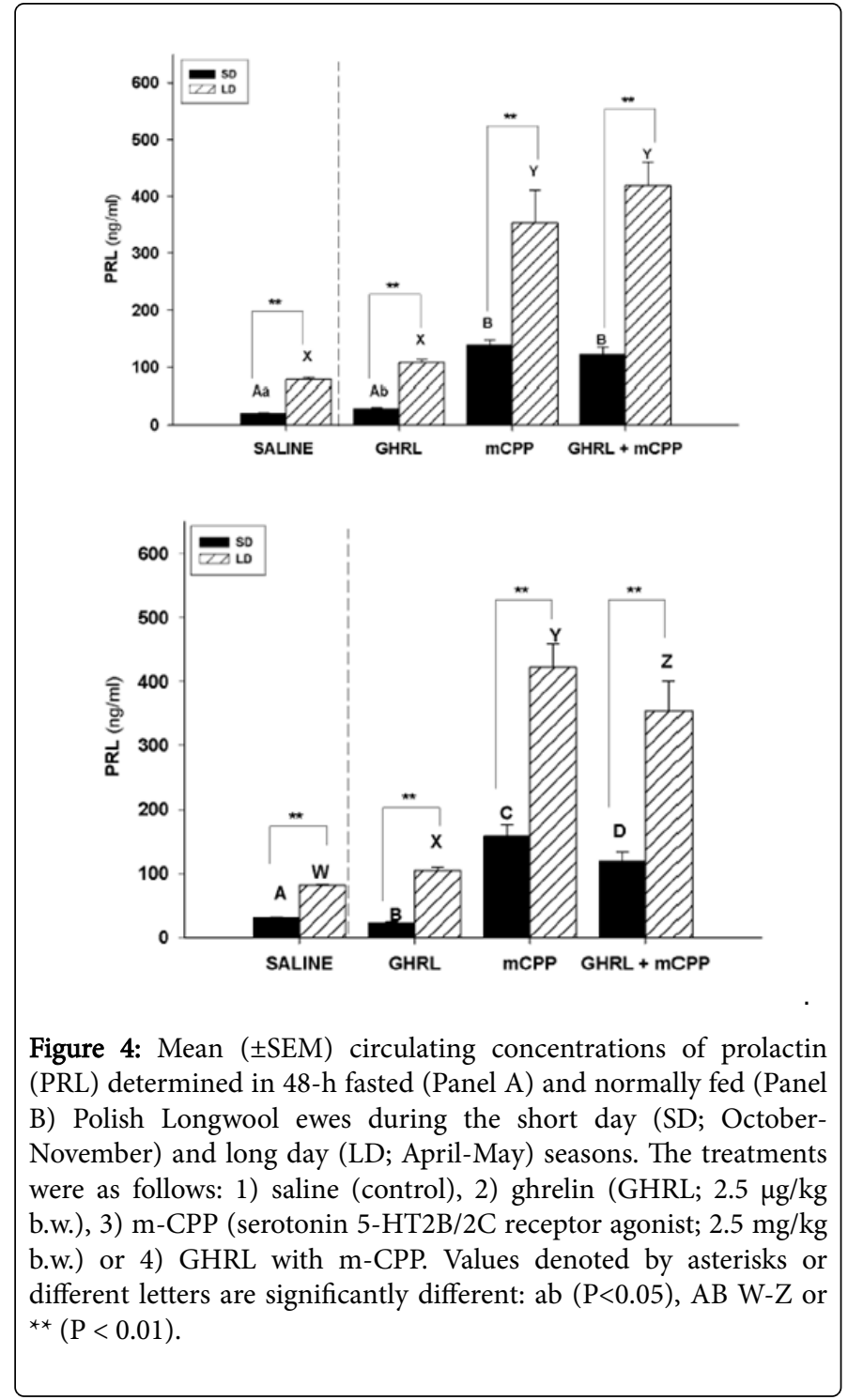

GH secretion in ruminants increases following chronic food restriction. In the present study, differences in mean circulating concentrations of GH between the dietary groups were neither observed nor expected after the relatively brief period $(48 \mathrm{~h})$ of feed withdrawal, consistent with Amstalden et al. [20] and Zieba et al. [11]. However, a higher mean GH concentration was observed in both dietary groups of sheep under LD conditions (all treatments) compared to SD (all treatments). A similar profile of mean circulating GH concentration was observed by Harrison et al. [21], who investigated the effect of photoperiod on $\mathrm{GH}$ and $\mathrm{LH}$ secretion in male sheep. The present study confirmed that both nutritional status and photoperiod may influence the effect of ghrelin on GH secretion [22]. Most importantly, our study also indicated that ghrelin signaling can be modulated, at least under certain physiological conditions in ewes, by the serotonin receptor agonist $\mathrm{m}-\mathrm{CPP}$. 
Citation: Zieba DA, Kirsz K, Szczesna M, Molik E, Romanowicz K, et al. (2015) Photoperiod Influences the Effects of Ghrelin and Serotonin Receptor Agonist on Growth Hormone and Prolactin Secretion in Sheep. J Neurol Neurophysiol 6: 301. doi: $10.4172 / 2155-9562.1000301$

Page 5 of 7

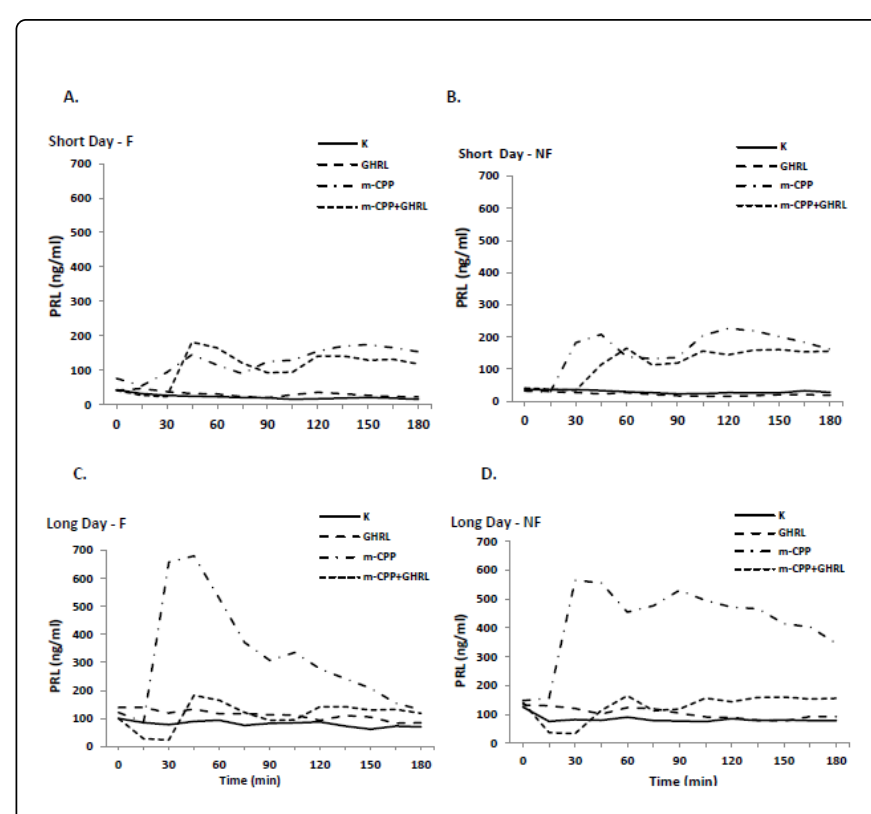

Figure 5: Temporal patterns of circulating prolactin (PRL) in samples collected at 15-min intervals collected from 48-h fasted (FPanels A and C) and normally fed (NF - Panels B and D) Polish Longwool ewes during the long day and short day seasons. The treatments were as follows: 1) saline (control), 2) ghrelin (GHRL; $2.5 \mu \mathrm{g} / \mathrm{kg}$ b.w.), 3) m-CPP (serotonin $5-\mathrm{HT} 2 \mathrm{~B} / 2 \mathrm{C}$ receptor agonist; $2.5 \mathrm{mg} / \mathrm{kg}$ b.w.) or 4) GHRL with m-CPP.

In a recent study, Prevot et al. [23] established a new physiological concept in the regulation of energy homeostasis by demonstrating that the nutritional status of an individual modulates the permeability of discrete blood hypothalamus barriers to circulating metabolic signals, thereby permitting them to directly access a subset of hypothalamic neurons. In seasonal breeding ewes, the photoperiodic signal melatonin, a lipophilic molecule, can easily penetrate the cerebrospinal fluid (CSF). Thus, melatonin can directly influence the hypothalamus and pituitary to modulate the activity and secretion of hormones [24]. In sheep, a particularly high number of melatonin receptors are located in the area of the third brain chamber, which is in the vicinity of the suprachiasmatic nucleus and other hypothalamic structures as paraventricular nucleus $(\mathrm{PVN})$, and neurotransmitters that regulate food intake and appetite are active in these hypothalamic areas [25]. One potential response of PVN neurons to metabolic and orexigenic stimuli from ghrelin-containing neurons is to activate the cellular signal transduction pathway downstream of the 5-HT2C serotonin receptor. Experiments have demonstrated that ghrelin has an inhibitory effect on the secretory activity of serotonin-releasing neurons in the hippocampus [26]. Clearly, there is a physiological basis for cross-talk between ghrelin and serotonin in the regulation of pituitary gland secretory activity. Our results also support an influence of photoperiodic cues and nutritional status on the effects of ghrelin and serotonin on GH release in ewes. In the present study, ghrelin increased GH concentrations only in fasted animals during LD photoperiods. A similar effect of ghrelin on GH release was recently observed in ovine pituitary explant cultures [27]. Treatment with m$\mathrm{CPP}$, nullified the stimulatory effects of ghrelin in fasted ewes but enhanced somatotropin release in normally fed animals with a more pronounced effect during the LD season. However, combined treatment with exogenous ghrelin and $\mathrm{m}$-CPP produced the same results as treating fasted ewes with ghrelin alone, and the combined treatment partly reduced the stimulatory effects of m-CPP on GH secretion in non-fasted sheep, particularly during the LD season.

PRL secretion is stimulated by ghrelin in humans and non-human primate [28]. In our experiment, ghrelin increased PRL secretion in fasted ewes during LD but decreased PRL production in fasted and non-fasted sheep during the SD period. In addition, ghrelin significantly augmented PRL secretion during the LD season in normally fed animals, thereby indicating that the effects of ghrelin on PRL secretion are both season- and nutrition-dependent, as previously postulated by Forbes et al. [29] based on a study in growing lambs. Garin et al. [30] suggested that ghrelin inhibits PRL secretion in rodents by elevating the serotonergic tone. The inhibitory effects of ghrelin on PRL secretion in the ewes in the present study were mainly observed in non-fasted ewes during the SD season. It is also possible that ghrelin partially reduced the $\mathrm{m}$-CPP-induced increase in PRL concentrations in normally fed ewes during the SD and LD seasons but not in fasted animals during either photoperiod. Increased PRL secretion was consistently observed after treatment with m-CPP in all animals during both seasons, in agreement with a human study on the $\mathrm{m}$-CPP influence on concentrations of PRL by Coccaro and Kavoussi [31].The orexigenic peptide ghrelin plays a key role in the homeostatic control of appetite [32]. Due to its involvement in the generation of hedonic signals for food intake, the ghrelinergic system may have potential as a therapeutic target to treat obesity and eating disorders [33]. Moreover, there is evidence that ghrelin has important extrahypothalamic functions, including in learning, memory, reward, motivation, anxiety, depression and neuroprotection [34]. Serotonergic neurotransmission also plays an important role in both satiation and food reward [35].

PRL concentrations following oral administration of the serotoninreleasing agent fenfluramine hydrochloride have been extensively used in medical practice to evaluate central serotonergic function in affective and related disorders [36]. Seasonal changes in the photoperiod regulate mood-related behavior and physiology in mammals, including humans [37]. Adam and Findlay [38] emphasized that sheep provide a valuable model to study the neuroendocrine aspects of the transfer of most circulating factors across the bloodbrain barrier. The easy access to CSF in large animals as opposed to rodents is clearly advantageous. Collu et al. [39] demonstrated that intraventricular injections of serotonin stimulate secretion of GH in rat, and they proposed that GH secretion is controlled through serotoninergic pathways in rats. In the present study, we demonstrated that $\mathrm{m}$-CPP stimulates GH secretion under SD and LD conditions in normal fed sheep. Laborit [40] noted that serotonin and its pineal derivative, melatonin, may have opposing effects on the secretion of GH. Similarly, in the present study, a decrease in GH secretion was observed during the SD season in fasted ewes, and an increase in GH was observed during the LD and SD seasons in normal fed sheep. Furthermore, ghrelin may have increased GH secretion in the fasted sheep during the LD season. The mechanisms underlying the ghrelin and melatonin interaction in sheep remain elusive. Ghrelin may attenuate the production of melatonin by inhibiting serotonin synthesis and secretion in pinealocytes [22]. Thus, there is a need for additional research on the relationship between serotonin and ghrelin in the context of the synthesis and secretion of melatonin from the pineal gland. 
Citation: Zieba DA, Kirsz K, Szczesna M, Molik E, Romanowicz K, et al. (2015) Photoperiod Influences the Effects of Ghrelin and Serotonin Receptor Agonist on Growth Hormone and Prolactin Secretion in Sheep. J Neurol Neurophysiol 6: 301. doi: $10.4172 / 2155-9562.1000301$

Page 6 of 7

\section{Conclusion}

In conclusion, this is the first study to assess the orchestrated effects of ghrelin and the serotonergic system on GH and PRL secretion in seasonally polyestrous animals varying in metabolic energy status. The results indicate that serotonergic systems operating via the $5-\mathrm{HT} 2 \mathrm{C}$ receptor and ghrelin are both involved in the regulation of $\mathrm{GH}$ and PRL secretion in sheep. Prolactin and ghrelin effects are seasondependent and affected by the nutritional status of the ewes. These results are consistent with ghrelin and the serotonergic system operating as metabolic cues in the maintenance of energy homeostasis with changes in food availability in the environment. However, the effect of photoperiod is significant and overrides the nutritional background in animals.

\section{Acknowledgment}

This work was supported by the Polish National Science Center (grant NCN 2012/05/B/NZ4/02408).

\section{References}

1. Kojima M, Hosoda H, Date Y, Nakazato M, Matsuo H, et al. (1999) Ghrelin is a growth-hormone-releasing acylated peptide from stomach. Nature 402: 656-660.

2. Iqbal J, Kurose Y, Canny B, Clarke IJ (2006) Effects of central infusion of ghrelin on food intake and plasma levels of growth hormone, luteinizing hormone, prolactin, and cortisol secretion in sheep. Endocrinology 147: 510-519.

3. Davenport AP, Bonner TI, Foord SM, Harmar AJ, Neubig RR, et al. (2005) International Union of Pharmacology. LVI. Ghrelin receptor nomenclature, distribution, and function. Pharmacol Rev 57: 541-546.

4. Delgado M, Ganea D (2008) Anti-inflammatory neuropeptides: a new class of endogenous immunoregulatory agents. Brain Behav Immun 22: 1146-1151.

5. Kaupmann K, Malitschek B, Schuler V, Heid J, Froestl W, et al. (1998) GABA(B)-receptor subtypes assemble into functional heteromeric complexes. Nature 396: 683-687.

6. Miller KJ (2005) Serotonin 5-ht2c receptor agonists: potential for the treatment of obesity. Mol Interv 5: 282-291.

7. Schellekens H, van Oeffelen WE, Dinan TG, Cryan JF (2013) Promiscuous dimerization of the growth hormone secretagogue receptor (GHS-R1a) attenuates ghrelin-mediated signaling. J Biol Chem 288: 181-191.

8. Johnston JD (2004) Photoperiodic regulation of prolactin secretion: changes in intra-pituitary signalling and lactotroph heterogeneity. Endocrinol 180: 351-356.

9. Otsuka T, Kawai M, Togo Y, Goda R, Kawase T, et al. (2014) Photoperiodic responses of depression-like behavior, the brain serotonergic system, and peripheral metabolism in laboratory mice. Psychoneuroendocrinology 40: 37-47.

10. Zieba DA, Kirsz K, Molik E, Romanowicz K, Wojtowicz AK (2011) Effects of orexigenic peptides and leptin on melatonin secretion during different photoperiods in seasonal breeding ewes: an in vitro study. Domest Anim Endocrinol 40: 139-146.

11. Kirsz K, Szczesna M, Molik E, Misztal T, Wojtowicz AK, et al. (2012) Seasonal changes in the interactions among leptin, ghrelin, and orexin in sheep. J Anim Sci 90: 2524-2531.

12. Zootechniki Instytut (1993) Nutrient Requirements for Cattle and Sheep in the Traditional System (in Polish), sixth ed. Krakow: Norms. Zespol Wydawnictw i Poligrafii 67-86.

13. Aloi JA, Insel TR, Mueller EA, Murphy DL (1984) Neuroendocrine and behavioral effects of $\mathrm{m}$-chlorophenylpiperazine administration in rhesus monkeys. Life Sci 34: 1325-1331.
14. Dvorak P, Becka S, Krejci P, Chrpova M (1978) Radioimmunoassay of bovine growth hormone. Radiochem Radioa Lett 34: 166-170.

15. Wolinska E, Polkowska J, Domanski E (1977) The hypothalamic centres involved in the control of production and release of prolactin in sheep. J Endocrinol 73: 21-29.

16. Ciofi $P$ (2011) The arcuate nucleus as a circumventricular organ in the mouse. Neurosci Lett 487: 187-190.

17. Langlet F, Mullier A, Bouret SG, Prevot V, Dehouck B (2013) Tanycytelike cells form a blood-cerebrospinal fluid barrier in the circumventricular organs of the mouse brain. J Comp Neurol 521: 3389-3405.

18. Skipor J, Mlynarczuk J, Szczepkowska A, Lagaraine C, Grochowalski A, et al. (2012) Photoperiod modulates access of 2,2',4,4',5,5' hexachlorobiphenyl (PCB153) to the brain and its effect on gonadotropin and thyroid hormones in adult ewes. Ecotoxicol Environ Saf 78: 336-343.

19. Szczesna M, Zieba DA2 (2015) Phenomenon of leptin resistance in seasonal animals: the failure of leptin action in the brain. Domest Anim Endocrinol 52: 60-70.

20. Amstalden M, Zieba DA, Edwards JF, Harms PG, Welsh TH, et al. (2003) Leptin acts at the bovine adenohypophysis to enhance basal and gonadotropin-releasing hormone-mediated release of luteinizing hormone: differential effects are dependent upon nutritional history. Biol Reprod 69: 1539-1544.

21. Harrison JL, Miller DW, Findlay PA, Adam CL (2008) Photoperiod influences the central effects of ghrelin on food intake, $\mathrm{GH}$ and $\mathrm{LH}$ secretion in sheep. Neuroendocrinology 87: 182-192.

22. Kirsz K, Zieba DA (2012) A review on the effect of the photoperiod and melatonin on interactions between ghrelin and serotonin. Gen Comp Endocrinol 179: 248-253.

23. Prevot V, Langlet F, Dehouck B (2013) Flipping the tanycyte switch: how circulating signals gain direct access to the metabolic brain. Aging (Albany NY) 5: 332-334.

24. Reiter RJ (1991) Melatonin: that ubiquitously acting pineal hormone. News Physiol Sci 6: 223-227.

25. Froy $\mathrm{O}$ (2010) Metabolism and circadian rhythms-implications for obesity. Endocr Rev 31: 1-24.

26. Ghersi MS, Casas SM, Escudero C, Carlini VP, Buteler F, et al. (2011) Ghrelin inhibited serotonin release from hippocampal slices. Peptides 32 2367-2371.

27. Hannibal J (2002) Neurotransmitters of the retino-hypothalamic tract. Cell Tissue Res 309: 73-88.

28. Deurveilher S, Semba K (2005) Indirect projections from the suprachiasmatic nucleus to major arousal-promoting cell groups in rat: implications for the circadian control of behavioural state. Neuroscience 130: 165-183.

29. Forbes JM, Driver PM, El Shahat AA, Boaz TG, Scanes CG (1975) The effect of daylength and level of feeding on serum prolactin in growing lambs. J Endocrinol 64: 549-554.

30. Garin MC, Burns CM, Kaul S, Cappola AR (2013) Clinical review: The human experience with ghrelin administration. J Clin Endocrinol Metab 98: 1826-1837.

31. Coccaro EF, Kavoussi RJ (1994) Neuropsychopharmacologic challenge in biological psychiatry. Clin Chem 40: 319-327.

32. Tena-Sempere M, Felip A, Gómez A, Zanuy S, Carrillo M (2012) Comparative insights of the kisspeptin/kisspeptin receptor system: lessons from non-mammalian vertebrates. Gen Comp Endocrinol 175: 234-243

33. Skibicka KP, Dickson SL (2011) Ghrelin and food reward: the story of potential underlying substrates. Peptides 32: 2265-2273.

34. Andrews ZB (2011) The extra-hypothalamic actions of ghrelin on neuronal function. Trends Neurosci 34: 31-40.

35. Donovan MH, Tecott LH (2013) Serotonin and the regulation of mammalian energy balance. Front Neurosci 7: 36 .

36. Newman ME, Shapira B, Lerer B (1998) Evaluation of central serotonergic function in affective and related disorders by the 
Citation: Zieba DA, Kirsz K, Szczesna M, Molik E, Romanowicz K, et al. (2015) Photoperiod Influences the Effects of Ghrelin and Serotonin Receptor Agonist on Growth Hormone and Prolactin Secretion in Sheep. J Neurol Neurophysiol 6: 301. doi: $10.4172 / 2155-9562.1000301$

Page 7 of 7

fenfluramine challenge test: a critical review. Int J Neuropsychopharmacol 1: 49-69.

37. Prendergast BJ, Nelson RJ (2005) Affective responses to changes in day length in Siberian hamsters (Phodopus sungorus). Psychoneuroendocrinology 30: 438-452.

38. Adam CL, Findlay PA (2010) Decreased blood-brain leptin transfer in an ovine model of obesity and weight loss: resolving the cause of leptin resistance. Int J Obes (Lond) 34: 980-988.
39. Collu R, Fraschini F, Visconti P, Martini L (1972) Adrenergic and serotoninergic control of growth hormone secretion in adult male rats. Endocrinology 90: 1231-1237.

40. Laborit H (1972) Correlations between protein and serotonin synthesis during various activities of the central nervous system (slow and desynchronized sleep, learning and memory, sexual activity, morphine tolerance, aggressiveness, and pharmacological action of sodium gammahydroxybutyrate). Res Commun Chem Pathol Pharmacol 3: 51-81. 